\title{
Interrogating the challenges and opportunities for entrepreneurs in the Fourth Industrial Revolution: a developing country perspective
}

\section{Ogunlela G. Oyebanjo and Robertson K. Tengeh*}

\author{
Cape Peninsula University of Technology, \\ Cape Town, South Africa \\ Email: ogunlelag@cput.ac.za \\ Email: tengehr@cput.ac.za \\ *Corresponding author
}

\begin{abstract}
The world is on the cusp of an epoch known as the Fourth Industrial Revolution (4IR). Despite the much-publicised promise of enhanced productivity, flexibility, efficiency and improved quality, Industry 4.0 is a daunting prospect for less-developed nations without the human labour to cope with and embrace the anticipated technological advancement. The paper explores the various opportunities and challenges associated with entrepreneurship in the Fourth Industrial Revolution in developing countries to ascertain their readiness. An in-depth, systematic literature review was conducted. In doing that, we were mindful of the coverage, and data collection was carried out through a rigorous process to ensure the accuracy of findings while keeping the study's objective. This paper argues for entrepreneurs to rethink and initiate the development of strategies that would make them relevant in the future, through innovation of business models, in preparation for possible disruptions with the evolution of Industry 4.0, while also advocating that more should be done to address the causes of policy and institutional failures.
\end{abstract}

Keywords: 4IR; Fourth Industrial Revolution; Industry 4.0; entrepreneurship; economy; innovation; opportunities; developing countries.

Reference to this paper should be made as follows: Oyebanjo, O.G. and Tengeh, R.K. (2021) 'Interrogating the challenges and opportunities for entrepreneurs in the Fourth Industrial Revolution: a developing country perspective', World Review of Entrepreneurship, Management and Sustainable Development, Vol. 17, No. 6, pp.883-896.

Biographical notes: Ogunlela G. Oyebanjo is a Research Fellow at the Cape Peninsula University of Technology, South Africa at the Department of Entrepreneurship and Business Management, in the Faculty of Business and Management Sciences. His research interest is green entrepreneurship, integrated supply chain management, entrepreneurship, disruptive innovation and 4IR.

Robertson K. Tengeh is an Associate Professor and Head of the Department of Public Administration and Governance at the Cape Peninsula University of Technology in South Africa. His research interests include entrepreneurship and small business management. 


\section{Introduction}

The evolution of technology is fast affecting all facets of life and transforming how people live and work. The Fourth Industrial Revolution (4IR) or Industry 4.0 is, according to Schwab (2016), the "Fusing of physical, digital and biological spheres", which impacts every area of endeavour, from industries to government, and from economies to education and human beings, with its related technological advancement, evidenced by changes happening in our immediate environment in an excessive way (Schwab, 2016). While technology advancement could have a positive impact on economic development this is, nevertheless, there are concerns as Industry 4.0 is also anticipated to have an adverse effect on employment, resulting in job losses and probable insecurity (Brown-Martin, 2017). This assertion was supported by the World Economic Forum (WEF, 2016) regarding the future of work, in stating that " $65 \%$ of children entering primary school today will ultimately end up working in completely new job types that do not yet exist". Therefore, the introduction of robotics and other information technology (IT) innovation into the workplace gives cause for concern and subsequently leads to anxiety on the part of workers globally (Brown-Martin, 2017). Most jobs that could be lost due to innovation are evident and may have been identified, however, the issue of which job type would be identified and how most employees may be best prepared to take up future opportunities is uncertain (Brown-Martin, 2017).

Innovative business models could, nevertheless, assist in this regard. Drobyazko et al. (2019) describes an innovative business model as an approach to conducting business that ensures competitive stability and the rapid growth of an enterprise. One may argue that sustaining the business model would require the continuous creation of value, also referred to as innovation. More so, Drobyazko et al. (2019) concur that the use of business modelling involves implementing comprehensive economic validation that is analytical, graphical and programmatic, in making the best choice for an enterprise's strategic development, specifically where allocation of the formation and development stages of a business model is concerned, based on individual characteristics, factors and conditions.

Where Schumpeter is concerned, it is "the entrepreneur's ideas, creativity and vision of the world" that make the difference in creating "new combinations, to change existing business models, and to innovate" (Burger-Helmchen, 2012). It is further held by Reinert and Reinert (2006) that entrepreneurship utilises what Schumpeter referred to as "the gale of creative destruction" to either completely or partially change or supersede offerings that are inferior across markets and industries, while simultaneously creating new business models and products, making creative destruction responsible in large part, for long-term economic growth.

With South Africa (SA) caught in the 'global hype' of Industry 4.0 and where entrepreneurship, innovation and the effect on the economy are concerned, questions that come to mind include, how entrepreneurs prepare for this drastic change in roles and responsibilities, in addition to how they will thrive with full implementation of Industry 4.0, looking into the future? Moreover, it is questioned how government can ensure the economic environment is conducive to entrepreneurship growth and development? According to Brown-Martin (2017), it is anticipated that new venture creation would serve as a source of employment and economic advancement, however, entrepreneurs 
could only thrive and flourish when government ensures an enabling environment for entrepreneurs to succeed and encourages a lifelong learning mindset amongst individuals and workers.

In a study conducted by Deloitte Insight (2018), where in the opinion of some executives in South Africa (SA) was sampled and compared with their global counterparts in 19 countries, including SA, to determine their organisations' readiness for Industry 4.0 uptake; their findings indicated doubt amongst executives, where their organisations' preparedness for imbibing Industry 4.0 initiatives are concerned, as only four percent indicated confidence in resulting opportunities being harnessed. This is a clear indication of potential looming danger that could adversely impact most organisations' existence and competitiveness, considering the role played by entrepreneurs in any economy (Deloitte Insight, 2018).

A high unemployment rate characterises SA, despite the government instituting numerous opportunities to reduce this phenomenon and potentially encourage entrepreneurship to start new business ventures. Unfortunately, a substantial number of new ventures fail shortly after inception - between their first and fifth year, while $70 \%$ close down within their first five to seven years of operation (Lings, 2014; Bushe, 2019). The International Leadership Development Program (ILDP, 2014) report states that the wholesale and retail sectors, predominantly made up of small, micro and medium enterprises (SMMEs), contribute up to $12.5 \%$ of SA's Gross Domestic Product (GDP), employing more than $50 \%$ of the SA workforce and as such, failure of these enterprises impacts employment and socio-economic activities substantially, along with increased poverty, and the rate and types of crime.

A Small Enterprise Development Agency (SEDA) report on SMMEs shows a reduction $(2.48 \%$ to $2.44 \%$ ) in the number of SMMEs in SA from 2017 quarter three to 2018 quarter one, hence a 1.4\% drop (SEDA, 2018). Employment provided by SMMEs additionally declined from eight million people to 6.44 million people within six months (SEDA, July 2018). Lings (2014) argued that most jobs in SA were created by the Small and Medium Enterprises (SME) sector. Nevertheless, large corporations also contribute to employment, although minimally, with much of their energy focused on increasing their output due to the anticipated technology adoption with the advent of Industry 4.0, which could cause business disruption through innovation and technology. In anticipation of creating jobs for SA's unemployed, the government should focus its attention on establishing a more conducive environment for SMEs to thrive (Lings, 2014).

The importance of SMMEs cannot be overemphasised, with the forecast that by 2030 , these small enterprises are expected to be the source of approximately $90 \%$ of jobs in SA (Zeenat, 2018). However, between 70 to $80 \%$ of SMEs barely survive their first year of operation (SEDA, July 2018). Furthermore, only about nine percent of small businesses in SA manage to make it to a 10-year mark, even without disruption (SEDA, July 2018). Given SME's potential and their expected role in contributing to job creation and growth in SA, their lack of requisite skills and necessary infrastructure that could allow Industry 4.0 introduction is worrisome.

The paper focuses on disruptions to production, infrastructure, the economy, business, and human labour, limiting entrepreneurship success in the 4IR. A conceptual approach was thus used, through an in-depth literature review, to identify and discuss the key features of Industry 4.0, its relationship with entrepreneurship, its impact on their business operations in SA, as well as the key drivers of and factors influencing Industry 4.0 readiness, along with its implication for an organisation's workforce. The following 
section discusses the interconnection between Industry 4.0 and Entrepreneurship, followed by Industry 4.0 Challenges and Opportunities, then Industry 4.0 and the future of Entrepreneurship, Limitation, Implication for Entrepreneurs and Policy Makers and lastly, the Conclusion.

\section{Methodology}

This article intended to ascertain the opportunities and challenges confronting entrepreneurship in the digitally driven Fourth Industrial Revolution (4IR). The research focused on South Africa, where high rates of business failure, unemployment and poverty exist. To attain the objective of this study, a desktop, qualitative method which followed the existing literature analysis approach was adopted (Opute et al., 2020).

A descriptive literature survey method was used because of its suitability and ability to help gain adequate insight into previous research relevant to the study in a research project. We used keywords and other relevant strings to search for articles related to the central theme of this study. As such, we engaged a review strategy that will assist us in gathering a vigorous substantiation relating to the main themes of our study which will allow systematic and explicit methods to classify, hand-pick, and conduct evaluation of appropriate literature linking to a specific thesis or central question of a study (Cronin et al., 2008; St. John and McNeal, 2017).

We concluded with the development of an understanding of the need to recognise the importance of 4IR in entrepreneurial sustainability and development; the key features of Industry 4.0, its relationship with entrepreneurship, its impact on their business operations in SA, as well as the key drivers of and factors influencing Industry 4.0 readiness, along with its implication for an organisation's workforce and the economy.

In order to ensure that accurate information was gathered, we engaged in the process of back and forth reading and revision (Straus and Corbin, 1998). Hence, the data obtained from the literature review reflected a range of theoretical perspectives or conceptualisations of viewpoints (Snyder, 2019). Through our data collection and analysis, we could draw conclusions and frame implications in line with our central theme and determine areas for future study.

\section{Literature review}

\subsection{The interconnection between Industry 4.0 and entrepreneurship}

Entrepreneurship has aroused much attention as an avenue for employment, fostering economic growth in developed and developing countries (Acs et al., 2008; Stam et al., 2008). An increased quest to address socio-economic problems and reduce poverty has adjudged entrepreneurship to be an avenue for people to be lifted out of poverty and contribute to a country's increased economic development (Barringer and Ireland, 2016), helping less-developed countries to adopt and adapt to innovation and become industrialised (Dodgson et al., 2008).

Industry 4.0 is characterised by advancement in technology, innovation, digitisation and the blurring or fusion of physical, biological and cyber aspects of life (Minhas, 2019), with these advancements in technology seen as a continuation of the digital 
revolution of the third industrial revolution (3IR) (Minhas, 2019). Although Industry 4.0 is assumed to be a proliferation of industrial advancement, Minhas (2019) argued that the phenomenon of the way Industry 4.0 and innovative advancement impact human beings could be perceived as developmental in nature and regarded as an advancement of the 3IR, rather than a new technological development, as widely believed (Kodama, 2018). Entrepreneurship serves as a connection between the 3IR and 4IR (Naudé, 2017). Nonetheless, entrepreneurship could be viewed as an easy initiative or the hinge that demonstrates human economic advancement. Either perspective highlights the crucial role played by entrepreneurs in any economy's industrial transformation process.

According to Schumpeter (1934, p.78), "everyone is an entrepreneur only when he actually carries out new contributions and lose that character as soon as he has built up his business, when he settles down and is running it as other people run their business". Additionally, Minhas (2018) defined entrepreneurship as business undertaken by someone confronted with enormous risk and immense challenges in the conduct of either setting up or running a business to make a profit through combining innovative ideas, leadership, motivating people, and decision-making that harnesses resources, their allocation and use, in an efficient and effective way, ensuring profitability of the business (Minhas, 2018). Thus, collaboration and initiative are important characteristics of an entrepreneur.

As explained by Minhas (2019), society is confronted with a series of socio-economic problems, solvable through innovative ideas and technology advancement, and in doing so, an entrepreneur could be a catalyst to the required change necessary to improve the economy. Further stressed, was that these entrepreneurs apply entrepreneurship initiatives through combining innovation and offering solutions to economic problems (Minhas, 2019). Important to note is that the old ways of conducting business face challenges potentially limiting many entrepreneurs' competitiveness going forward. Fortunately, with Industry 4.0 adoption and implementation, entrepreneurial ability to collaborate effectively and make the best use of technology and innovation allows for a better chance of fulfilling their objectives.

Globally, entrepreneurship has become an important element of the debate, and its relationship to economic activities and society (Besant and Tidd, 2014) and, most importantly, its role in economic growth and development cannot be ignored. Many studies have investigated the economic development concept and the role of entrepreneurship (for example, Harper, 2003; Walzer, 2009; Braunerhjelm, 2010; Naudé, 2011; Ács et al., 2013). According to Toma et al. (2014), globally, governments, policymakers and organisations iterate entrepreneurship's importance and substantial contribution to economic development. Previously, emphasis was on most large corporations as the main stakeholders in economic development, but this has seen a recent change, with attention shifting to consider the SME sector and new start-up enterprises that contribute substantially to economic development, not only as "a key mechanism for enhancing economic development, particularly in regions where entrepreneurial activities were once vibrant and are now lagging", but also as "a good solution because it provides a relatively non-controversial way to increase the proverbial pie, creating jobs and enhancing per capita income growth" (Shane, 2005, p.1). According to Dana (2006) iterate that SMEs are important and needed in most countries, this is for them to help handle those business activities that big corporations have neglected due to the cost of carrying out the activities. Furthermore, it is assumed that big 
corporations seem not to make much profit when they engage in such smaller activities, as such, this invariable create an avenue for SMEs to thrive and position themselves in the existing market.

Beginning from the 1980s and through the 1990s, SMEs role was evaluated appropriately, subsequently leading to scrutiny of entrepreneurship because of the high global unemployment problem (Wennekers and Thurik, 1999). As Toma et al. (2014) explained, this initiative led to various stakeholders showing more interest in the SME sector's importance; even more recognised in the 1980s due to SMEs ability to help create roughly $80 \%$ of jobs in the United States of America (USA), which has since continued. SMEs in the USA contributed since 1980 till date approximately 50\% of the GDP, as well as exports, as did Latin America, in realising SMEs are a job creation catalyst (Toma et al., 2014), while most Asian countries' economic growth depends on SMEs, with approximately $80 \%$ of workers employed by SMEs, as an example.

In general, the Sub-Sahara Africa (SSA) economy, and SA in particular, is characterised by unemployment, even though Sub-Sahara Africa is adjudged as a young region that will accommodate $60 \%$ of youth younger than 25 years by 2030 (WEF, 2016). Most countries in this region are somewhat agitated about the potential Industry 4.0 impact on entrepreneurship, specifically, regarding future work (Job loss), skills disruption and shortages due to a lack of skills in vital Industry 4.0 professions, anticipated to negatively impact entrepreneurship and subsequently, economic growth (Naudé, 2017). In spite of these challenges, Industry 4.0 will continue to impact jobs, especially with the introduction of robotics to replace humans (WEF, 2016), creating concern as to how entrepreneurs would respond and embrace technological advancement. Millington (2017) asserted that this advancement would positively impact social aspects of life, the economy, and employment while increasing production, enhancing new product development, and effective corporate market entry.

Industry 4.0 would introduce many opportunities into the SA economy, specifically the SME sector, while helping most entrepreneurs to improve their business through implementing innovative technologies to enhance their competitiveness (Millington, 2017). This initiative could be food for thought for policymakers, regarding how to provide the necessary support required to improve industrialisation in SA. A major concern regarding technology evolution is the astronomical rate at which it is evolving (Naudé, 2017) and how it affects workers with low skills, thus impacting their continued employment. Therefore, the extent of SA's preparedness as a country and whether entrepreneurs can successfully negotiate this technology storm are of concern, considering the high rate of unskilled workers and catching up with the pace at which technology is evolving (Millington, 2017).

Ogwo (2018) mentioned the worrisome and inadequate education and training investment that could further deepen the challenge, together with skills shortages in some sectors and its impact on the readiness and extent of entrepreneurs' participation in Industry 4.0. Entrepreneurship, entrepreneurs and the SA workforce will be positively and negatively impacted regarding the unpredictable Industry 4.0 disruption to the business. Nkala (2019) highlighted some adverse effects already posed to business, such as digitisation resulting in many branches being closed in the financial sector, while robotics and additive manufacturing in production will replace most humans, with mostly low income earners in the country living in townships feeling the impact of Industry 4.0 
more acutely (Nkala, 2019). Entrepreneurs are anticipated to emerge from these groups, with most enabling infrastructure allowing participation in Industry 4.0 not readily available.

This further implies that most entrepreneurs in Africa in general, including SA, may not be prepared for this technology evolution when compared to most developed nations (Entrepreneur Square, 2019), where entrepreneurs are developing strategies to enable embracing and facing the potential challenges. In most parts of SA, there is no infrastructure to enhance participation in the new business landscape. Gavaza (2019) explained that, in a speech by George Friedman at an Industry 4.0 meeting in July 2019, Friedman expressed the opinion that SA has not harnessed the opportunity of the previous industrial revolution and should probably refocus on how to lift citizens out of poverty, through advancing entrepreneurship and business that can employ most unskilled people.

Runde and Milner (2019) echo this in their reference to "a developing country phenomenon", even as they concur that developing countries experience the same Industry 4.0 at present, they also highlight this is being done in very different ways. Many countries are, as determined by the CSIS Report on prosperity and development (Runde and Milner, 2019, p.3), in effect undergoing "all the industrial revolutions at the same time. Countries from Africa to Asia and Latin America to Eastern Europe are simultaneously urbanising and industrialising for the first time". This is evidenced by their building of 2IR and 3IR infrastructure, while at the same time "powering emergent production and manufacturing with technology rather than people while also adopting the technologies of technology quicker than developed countries."

\subsection{Industry 4.0 challenges and opportunities}

Petrillo et al. (2018) argued that Industry 4.0 is a drastic change in technology, leading to a fusion of the cyber and physical aspects of life and how work is done through the use of innovative technology. While industrial revolution has passed through three stages and has been adequately harnessed in most developed countries, mostly in an advantaged position and now leapfrogging into Industry 4.0 (Lasi et al., 2014), thus making Industry 4.0 a disruptor in the process of industrialisation, leading to changes in the economy and society at large.

Industry 4.0, according to the Economist (2012), could be assumed to be a continuation of the Third Industrial Revolution (3IR), however, the chief production officer of the BMW Group, Harald Kruger, has a contrary opinion seeing it as a major change necessitating an enormous move towards digitisation, thus making it a continuous technology development that, when implemented by organisations, would help to increase their productivity, resulting in their being more flexible (Berger, 2014).

Prediction of Industry 4.0 opportunities is fairly obvious, as it will firstly lower barriers between inventors and markets, and secondly, open avenues for AI to play a more active role with, thirdly, fusion or integration of different techniques and domains with, fourthly, improved life quality through robotics and lastly, the connected life provided by the IoT (Xu et al., 2018). Hence, most leading corporations believe this radical technological digitisation advancement change would affect "countries economy, business and human labour" (Petrillo et al., 2018, p.3), and lead to association amongst intelligent machines, storage mechanisms, as well as production, to form intelligent networks, through real-world, in cyber-physical systems. These technologies will thus 
bring about "smart" factories, with enhanced custom product development that will leapfrog into opportunities, improving production efficiency and flexibility in operations (Petrillo et al., 2018). In short, a requirement for full Industry 4.0 adoption by various stakeholders depends on the requisite skills needed to respond to anticipated change and innovation. Further, Petrillo et al. mentioned that, in developed countries, the challenges attributed to Industry 4.0 are classified broadly into three major groups;

- The need for experimentation and learning to give way for companies to strengthen their business;

- Data explosion, to send information more quickly and increase data volume;

- Transforming the workforce, integrating the system operator with new skills that enable working digitally to assist cyber-physical systems.

Nevertheless, the problems facing developed countries seem to be more advanced than those of developing countries, while both reflect skills development as crucial; these problems have been identified (Petrillo et al., 2018) as:

- Training of personnel in specific areas relating to managing digital jobs;

- Lack of scalability as few entrepreneurs have the requisite skills how to implement Industry 4.0 in their system;

- Lack of funding to start planning at the various levels of government (national, provincial and local) for implementation in terms of infrastructure and other factors.

Since change in an organisation could face much resistance, it is important to develop adequately equipped leaders to lead the anticipated change, otherwise, the implementation may fail (Petrillo et al., 2018). Moreover, uncertainties associated with return on investment could be a limiting factor. At the same time, another crucial challenge identified is cyber security (data), with the need to protect the environment to avoid intrusion into the system and loss of confidential data where competitiveness is affected. Amid the various challenges confronting entrepreneurship in the Industry 4.0 era, there are enormous opportunities this presents to the world of business, which entrepreneurs can tap into to be relevant in the new dispensation.

$\mathrm{Xu}$ et al. (2018) mentioned the the industrial revolution could be thought of as the 'hunter and gatherer' age and described through the five characteristics to model the opportunities with Industry 4.0. This assertion affirms that each revolution builds on the previous and as such, opportunities and gains increase with the new industrial revolution's introduction. Further, they iterate that existing jobs in the previous revolution may either be reduced or cease to exist when the new revolution transpires. Industry 4.0 will affect all stakeholders, from government to business (Entrepreneurs), to people and society at large (Xu et al., 2018), with less technology control and or disruption by people evident in Industry 4.0. Consequently, prediction of the possible opportunities of Industry 4.0 are therefore feasible as follows; AI will be put to use more in all facets of life and most especially in businesses; Robotics will be adopted to improve quality of life and business; the IoT will be used for device connectivity to enhance monitoring and control; and difficulties hindering the connection between entrepreneurs and markets will be reduced or eliminated, while the integration of techniques and domains will be possible. 


\subsection{Industry 4.0 and the future of entrepreneurship}

The most pertinent question is whether entrepreneurs are ready to embrace Industry 4.0, globally, in general and in particular, in SA. Some questions on Industry 4.0, according to Tutu and Burgess (2018), include: what are the prospects of Industry 4.0 in developing countries in general and particularly in Sub-Sahara Africa? Is Industry 4.0 relevant to entrepreneurship? Is Sub-Sahara Africa ready for Industry 4.0? Also, Gavaza (2019) asks whether SA is ready for Industry 4.0? Answers to these questions point to the impossibility of entrepreneurs adopting and implementing Industry 4.0, based on the benefits gained from doing so. As Xu et al. (2018) explained, this will help eliminate the challenges preventing effective collaboration amongst entrepreneurs and their prospective market with the advent of $3 \mathrm{D}$ printing.

Going forward, it is further anticipated that AI will serve as a solution provider to challenging problems, leading to cost savings for entrepreneurs through innovation and helping improve much needed socio-economic growth to promote global economic transformation (WEF, 2016). Furthermore, AI will enhance the living standards of citizens, boost government productivity, entrepreneurial activities, as well as consumption patterns and increase per capita income (Makridakis, 2017), with substantial improvement in social settings and the way entrepreneurs work (Naudé, 2017).

In spite of all these Industry 4.0 opportunities presented, some challenges are part of the revolution, according to Schwab (2015), who argued that "...we stand at the brink of a technological revolution that will fundamentally alter the way we work, live and relate to one another. In its scale, scope and complexity, the transformation will be unlike anything humankind has experienced before. We do not yet know just how it will unfold, but one thing is clear; the response to it must be integrated and comprehensive, involving all stakeholders of the global polity, from the public and private sectors to academia and the civil society".

This is corroborated by Davidow (2014), who posited that advancement in innovation and technology, due to Industry 4.0, should embody some challenges as, with the introduction of robotics and AI by some entrepreneurs into their business, technology thus replaces humans, leading to job losses. Nevertheless, Industry 4.0 could have some favourable influences on entrepreneurship, for example, an Accenture (2018) survey indicated that the IoT would create economic opportunities for entrepreneurs globally and contribute to nations' GDP, empowering production across nations, potentially leading to outsourcing of production to developing countries.

However, WEF (2017) is sceptical about entrepreneurs' readiness to embrace Industry 4.0 fully in Sub-Sahara Africa due to the lack of adequate policy implementation in the past and the attitude towards technological innovation frameworks that could be conducive to full entrepreneurial participation in Industry 4.0. IT infrastructure serves as a bedrock for Industry 4.0 to thrive, yet, broadband access by most Sub-Sahara Africa citizens and entrepreneurs is worrisome, as government investment in ICT is discouraging (Millington, 2017), with this deficiency limiting business process efficiency and effectiveness. It is perceived from the aforementioned that these deficiencies, most especially infrastructure and skills development, would substantially negatively impact entrepreneurship in SA.

Nonetheless, while wage stagnation is faced by many developing economies, along with what Runde and Milner (2019, p.4) refer to as "jobless growth," in addition to the 
problems associated with "creating meaningful work opportunities for their citizens", the authors also highlight the need for "a shift from just enabling technological change to understanding what new technologies mean for people".

Where innovative models and economy are concerned, Drobyazko et al. (2019) explain that competition tools are the main advantages of innovative business models in the enterprise's competitiveness instead of traditional models. The authors hold that "Unlike classical methods involving innovations in one or two areas of the economic mechanism of an enterprise (for example, pricing or technology policy), the introduction of new business models will make significant changes to most of its elements", which includes a potential consumer's choice, the mechanism for profit management and a means to sustainably combine these.

\section{Limitation}

\subsection{Implication for entrepreneurs and policy makers}

The practical implication of this paper reveals the impact of the disruptive innovation model on entrepreneurship due to the proliferation of 4IR, it tried to provide necessary suggestions for entrepreneurs in SA to enhance their preparedness to embrace industry 4.0 in a manner to enhance their sustainability and competitiveness. Further, it suggests that for both entrepreneurs and policymakers, in an attempt to be fully integrated and participate in this revolution, entrepreneurs and economies would have to part with substantial amounts of money to upgrade skills and infrastructure at various levels, both in private and government institutions. Entrepreneurs should have a radical change in business model, improved technological advancement in digitisation is a necessity, however, years of slow Internet uptake, for one, have found most African counties below the " $20 \%$ critical mass" required to enjoy connectivity effects and benefits (Gillwald and Mothobi, 2018, p.3). Moreover, the authors determined, even with readiness and skills training being vital, policymakers should address the causes of policy and institutional failures, as these act as challenges, negating innovative and sustainable entrepreneurial development opportunities, with proposals to overcome these, and lay a solid basis for SA to equitably prepare for Industry 4.0. It is also suggested that entrepreneurs rethink and develop strategies to make them relevant through innovation in preparation for potential disruptions with the evolution of technology.

Runde and Milner (2019, p.4) concur, stating that "People will either be empowered to contribute to world progress by technology or will be left to deal with issues we thought were exclusive to previous industrial revolutions." They further advocate that it is time to "think about the types of jobs, skills, and safety nets that economies especially those in the developing world - need to meet people's aspirations".

Considering the threatened future of entrepreneurship, through advancement in technology, innovation, digitisation and the blurring or fusion of both physical, biological and cyber aspects of life, all stakeholders, including government and private institutions should, as a matter of urgency, develop a strategy and business model that will offer room for skills upgrade of their workforce and development of the requisite infrastructure that will enable implementation of Industry 4.0. 


\section{Conclusion and limitations}

Globally, entrepreneurs and governments have mixed feelings about the potential effects of Industry 4.0 because of its potential impact on employment due to job losses to machines and similar technological inventions. This paper discussed how Industry 4.0 affects production, business, and employment and how technological advancements will affect the workforce in the future. However, the positive impact of technology advancement in production and the manner in which processes could be carried out by entrepreneurs and businesses are welcome. Unfortunately, the negative influence that technological disruption could cause to business operations and entrepreneurship is cause for concern, especially in nations unprepared to embrace Industry 4.0 or unable to catch up to the speed of its evolution.

Despite the possibilities offered by 4IR, there are challenges that entrepreneurs will have to overcome to succeed. The problems range from cybersecurity and economic meltdown to unemployment. 4IR and technological innovations will transform the way we work and live, however, we do not yet know how it will affect all facets of life. Entrepreneurs need to understand the current evolution of 4IR and how it will impact their organisations. In the case of South Africa, the preparedness by most entrepreneurs for the uptake of 4IR is unclear. For example, Deloitte (2018) conducted a study in 19 countries, including South Africa, to determine their preparedness for the 4IR adoption and implementation. Sadly, only $4 \%$ of the sampled executives indicate their preparedness, this is a clear indication of probable problems that could impede both the existence and competitiveness of most organisations. Therefore, for SA to tap into the opportunities that 4IR could present to entrepreneurs, organisations must begin to adjust their business models to give due consideration to the implications of 4IR and how it will impact their business and future of work, adequate staff training is also important, most especially in those areas relevant to 4IR due to high rate of unskilled workers for them not to be left behind due to the pace at which 4IR is evolving. Also, policymakers should create a conducive environment necessary to support entrepreneurship in the 4IR dispensation, especially in the rural area where there is a lack of adequate infrastructure to support 4IR.

This paper is conceptual, contributing to the evolving literature in sustainable business models, challenges and opportunities confronting entrepreneurship in the Fourth Industrial Revolution in developing countries. Therefore, it is suggested that empirical study is carried out to buttress the conclusions, for example, Quantitative and or mixedmethod study on entrepreneurship and fourth industrial revolution (4IR) in South Africa and other developing countries, to identify and discuss the key features of Industry 4.0, its relationship with entrepreneurship and its impact on their business operations in SA.

\section{References}

Accenture (2018) Accenture Technology Vision 2018 - Tech Trends Report. Available online at: https://www.accenture.com/_acnmedia/Accenture/next-gen-7/tech-vision2018/pdf/Accenture-TechVision-2018-Tech-Trends-Report.pdf\#zoom=50 (accessed on 15 February 2020).

Acs, Z.J., Desai, S. and Hessels, J. (2008) 'Entrepreneurship, economic development and institutions', Small Business, Vol. 31, No. 3, pp.219-234.

Ács, Z.J., Szerb, L. and Autio, E. (2013) Global Entrepreneurship and Development Index, Edward Elgar Publishing, Chelthenham, p.352. 
Barringer, B.R. and Ireland, R.D. (2016) Entrepreneurship: Successfully Launching New Ventures, 5th ed., Prentice-Hall, London.

Berger, R. (2014) Industry 4.0: The New Industrial Revolution-How Europe will Succeed. Available online at: https://www.rolandberger.com/media/pdf/Roland_Berger_TAB_ Industry_4_0_20140403.pdf (accessed on 15 January 2020).

Besant, J. and Tidd, J. (2014) Strategic Innovation Management, 3rd ed., Wiley, Chichester, UK, ISBN: 978-1-118-45723-8.

Braunerhjelm, P. (2010) Entrepreneurship, Innovation and Economic Growth, Working Paper 2010:02, pp.1-79.

Brown-Martin, G. (2017) Education and the Fourth Industrial Revolution, Prepared for Groupe Média TFO. Available online at: https://www.groupemediatfo.org/wpcontent/uploads/2017/12/FINAL-Education-and-the-Fourth-Industrial-Revolution-1-1-1.pdf (accessed on 28 December 2019).

Burger-Helmchen, T. (Ed.) (2012) Entrepreneurship Creativity and Innovative Business Models. Available online at: https://www.intechopen.com/books/entrepeneurship-creativity-andinnovative-business-models (accessed on 3 January 2020).

Bushe, B. (2019) 'The causes and impact of business failure among small to micro and medium enterprises in South Africa', Africa's Public Service Delivery and Performance Review, Vol. 7, No. 1, a210.

Cronin, P., Ryan, F. and Coughlan, M. (2008) 'Undertaking a literature review: a step by-step approach', British Journal of Nursing, Vol. 17, No. 1, pp.38-43.

Dana, L-P. (2006) Entrepreneurship and SMEs in the Euro-zone: Towards a Theory of Symbiotic Entrepreneurship, Imperial College Press, London.

Davidow, B. (2014) 'What happens to society when robots replace workers?' Harvard Business Review, 10 December. Available online at: https://hbr.org/2014/12/what-happens-to-societywhen-robots-replaceworkers

Deloitte Insight (2018) 'The Fourth Industrial Revolution is here-are you ready?' Deloitte Insights. Available online at: https://www2.deloitte.com/content/dam/Deloitte/tr/Documents/ manufacturing/Industry4-0_Are-you-ready_Report.pdf

Dodgson, M., Gann, D. and Salter, A. (2008) 'The Management of Technological Innovation: Strategy and Practice', Oxford: Economics, Vol. 31, No. 3, pp.219-234.

Drobyazko, S., Barwińska-Małajowicz, A., Ślusarczyk, B., Zavidna, L. and DanylovychKropyvnytska, M. (2019) 'Innovative entrepreneurship models in the management system of enterprise competitiveness', Journal of Entrepreneurship Education, Vol. 22, No. 4.

Economist, The (2012) The Third Industrial Revolution. Available online at: http://www.economist.com/node/21553017 (20 January 2020).

Entrepreneur Square (2019) 4th Industrial Revolution and the Future of Entrepreneurship in Africa. Available online at: https://www.entrepreneurssquare.com/4th-industrial-revolutionentrepreneurship/ (20 February 2020).

Gavaza, M. (2019) Is SA really ready for the fourth industrial revolution? Available online at: https:/www.businesslive.co.za/fm/fm-fox/digital/2019-07-18-is-sa-really-ready-for-thefourth-industrial-revolution/ (accessed on 28 November 2019).

Gillwald, A. and Mothobi, O. (2018) 'After Access 2018 - a demand-side view of mobile internet from 10 African countries', Research ICT Africa, pp.1-47.

Harper, D.A. (2003) Foundations of Entrepreneurship and Economic Development, Routledge, London, p. 280.

International Leadership Development Program (ILDP) (2014) Alp-Informal and SMME Retailers in South Africa, Industry_4_0_20140403.pdf Innovation', Technol. Mark. Complex., Vol. 4, No. 32.

Kodama, F. (2018) 'Learning Mode and Strategic Concept for the 4th Industrial Revolution', J. Open Innovation. Technol. Mark. Complex, Vol. 4, No. 32. 
Lasi, H., Kemper, H.G., Fettke P., Feld, T. and Hoffmann, M. (2014) Industrie 4.0, Springer Fachmedien, Germany, pp.239-242. DOI: 10.1007/s12599-014-0334-4.

Lings, K. (2014) The Missing Piece: Solving South Africa's Economic Puzzle, Pan McMillan, South Africa, Johannesburg.

Makridakis, S. (2017) 'The Forthcoming Artificial Intelligence (AI) Revolution: Its Impact on Society and Firms', Futures, Vol. 90, pp.46-60.

Millington, K.A. (2017) 'How Changes in Technology and Automation Will Affect the Labour Market in Africa', Helpdesk report on Knowledge, evidence and learning for development. Available online at: https:/opendocs.ids.ac.uk/opendocs/bitstream/handle/ 123456789/13054/ K4D_HDR_Impact $\% 20 \mathrm{of} \% 20$ automation $\% 20 \mathrm{on} \% 20 \mathrm{jobs} \% 20 \mathrm{in} \% 20$ Africa.pdf?sequence= 166\&isAllowed=y (accessed on 15 December 2019).

Minhas, W.A. (2018) Advancing Entrepreneurship in the United Arab Emirates: Start-up Challenges and Opportunities, Springer International Publishing, ISBN: 9783319764351.

Minhas, W.A. (2019) 'Future of Entrepreneurship in the 4th Industrial Revolution', Humanities and Social Sciences Review, Vol. 9, No. 1, pp.339-352.

Naudé, W. (2017) 'Entrepreneurship, Education and the Fourth Industrial Revolution in Africa', IZA Discussion Papers, No. 10855.

Naudé, W. (Ed.) (2011) Entrepreneurship and Economic Development, Palgrave Macmillan, New York, p.304.

Nkala, T. (2019) 4IR: The good, the bad and the inequality gap. Available online at: https://www.dailymaverick.co.za/article/2019-07-04-4ir-the-good-the-bad-and-the-inequalitygap/ (accessed on 30 December 2019).

Ogwo, B.A. (2018) 'Re-visioning Technical Vocational Education and Training (TVET) for the Youth in sub-Saharan Africa (SSA) and the Sustainable Development Goals (SDGs): Prospects and Promises Within the Framework of the Ubuntu Paradigm', in Takyi-Amoako, E. and Assié-Lumumba, N. (Eds): Re-visioning Education in Africa, Palgrave Macmillan, Cham, pp.155-173.

Opute, A.P., Irene, B.N. and Iwu, C.G. (2020) 'Tourism service and digital technologies: a value creation perspective', African Journal of Hospitality, Tourism and Leisure, Vol. 9, No. 2.

Petrillo, A., De Felice, F., Cioffi, R. and Zomparelli, F. (2018) Fourth Industrial Revolution: Current Practices, Challenges, and Opportunities. Available online at: http://dx.doi.org/10.5772/intechopen.72304 (accessed on 2 March 2020).

Reinert, H. and Reinert, E.S. (2006) Creative Destruction in Economics: Nietzsche, Sombart, Schumpeter. The European Heritage in the Social Sciences, Springer, pp.55-58.

Runde, D.F. and Milner, A. (2019) 'Evolution of Revolutions - The Human Element of Technological Change in Beyond Technology', in The Fourth Industrial Revolution in the Developing Word. A Report of the CSIS Project on Prosperity and Development, Center for Strategic \& International Studies (CSIS), Washington, pp.1-6.

Schumpeter, J.A. (1934) Capitalism, Socialism and Democracy, Harper, New York.

Schumpeter, J.A. (1934) The Theory of Economic Development, Harvard University Press, Cambridge.

Schwab, K. (2015) The Fourth Industrial Revolution: What It Means and How to Respond. Available online at: https://www.foreignaffairs.com/articles/2015-12-12/fourth-industrialrevolution (accessed on 10 February 2020).

Schwab, K. (2016) The Fourth Industrial Revolution, the World Economic Forum. Available online at: http://www.weforum.org/pages/the-fourth-industrial-revolution-by-klaus-schwab (accessed on 8 February 2020).

Shane, S. (Ed.) (2005) Economic Development through Entrepreneurship. Government, University and Business Linkages, Edward Elgar, Cheltenham, p.265.

Small Enterprise Development Agency (SEDA) (2018) SMME Quarterly Update 1st Quarter 2018. Available online at: http://www.seda.org.za/Publications/Publications/ SMME\%20Quarterly\%202018-Q1.pdf (accessed on 5 January 2020). 
Snyder, H. (2019) 'Literature review as a research methodology: an overview and guidelines', Journal of Business Research, Vol. 104, pp.333-339.

St. John, K. and McNeal, K.S. (2017) 'The Strength of Evidence Pyramid: One Approach for Characterising the Strength of Evidence of Geoscience Education Research (GER) Community Claims', Journal of Geoscience Education, Vol. 65, No. 4, pp.363-372.

Stam, E., Audretsch, D.B. and Meijaard, J. (2008) 'Renascent entrepreneurship', Journal of Evolutionary Economics, Vol. 18, No. 3.

Toma, S., Grigore, A. and Marinescu, P. (2014) 'Economic development and entrepreneurship', Procedia Economics and Finance, Vol. 8, pp.436-443.

Tutu, D.A. and Burgess, J. (2018) 'Is the fourth industrial revolution relevant to sub-Sahara Africa?' Technology Analysis \& Strategic Management, DOI: 10.1080/09537325.2018. 1542129.

Walzer, N. (Ed.) (2009) Entrepreneurship and Local Economic Development, Lexington Books, Lanham, p.286.

Wennekers, S. and Thurik, R. (1999) 'Linking entrepreneurship and economic growth', Small Business Economics, Vol. 13, No. 1, pp.27-55.

World Economic Forum (2016) The Future of Jobs: Employment, Skills and Workforce Strategy for the Fourth Industrial Revolution. Available online at: https://www.weforum.org/ reports/the-future-of-jobs (accessed on 15 January 2020).

Xu, X., Zheng, P., Lin, T. and Chen, C. (2018) 'A systematic design approach for service innovation of smart product-service systems', Journal of Cleaner Production, Vol. 201, pp.657-667.

Zeenat, V. (2018) '2 Common reasons why your business may be failing', Economy, 10 April 2018. Available online at: https://www.iol.co.za/business-report/economy/2-common-reasonswhy-your-business-may-be-failing-14348466 (accessed on 10 January 2020). 